\section{Profiting from reburial}

SIR-I wish to comment on Paul Bahn's account in News and Views ${ }^{1}$ of the First International Congress on the Reburial of Human Remains. The meeting was a scientific sham, a media event for the advocates of reburial ${ }^{2}$. Groups supporting preservation were excluded. Archaeologists and other researchers (including the forensic specialist Clyde Snow), who were scheduled to speak, were barred from the podium by the activists who took control of the meeting.

The reburial movement in the United States, often motivated by media attention, politics and money, masquerades as a religious or racial rights movement. But it has little concern for individuals' religious freedom or the rights of the true next-of-kin to claim their ancestors' remains ${ }^{3}$. At stake are large quantities of money being paid to 'native' site watchers and advisors (the $\$ 1,000,000$ recently paid to 'Indian watchers' for the Santa Barbara oil pipeline project, for example $e^{4}$.

Public money for reburials is the latest growth industry for numerous activists; $\$ 135,000$ of taxpayers' money was used to pay off land-owners, lawyers, archaeologists and activists in an effort to bury 146 poorly studied skeletons in Salina, Kansas ${ }^{5}$. Religious and historic traditions, accurate identifications and the desires of the next-of-kin have little influence on its many activists who demand reburial for all remains under a variety of selfstyled 'traditional' religions ${ }^{3}$. Thus Stanford University has released 550 Ohlone skeletons to individuals who had identified themselves with this tribe (the last recognized member of which died in the early $\left.1800 s^{6}\right)$.

Political compromises and legislation by misguided politicians, are bringing archaeology to a halt and are destroying many crucial collections of skeletons and artefacts. Yet many government scientists are silenced by intimidation, while museums are being forced to dispose of their collections. The Smithsonian Institution expects to lose a quarter of its skeleton collection in exchange for new building and more federal funding ${ }^{7}$. Yet professional scientific groups have mounted, for the most part, a poor and ineffective defence.

Reburial, with few exceptions, robs the world of important records of environment, life style and human endeavour. It seldom reflects the wishes of the direct descendants. These losses to science, as well as of money which, otherwise, could be used for better health care and education, will seriously affect medical research into cancer, diabetes and arthritis (which affect Native Americans more than any other faction of the general public) as well as cultural studies ${ }^{8}$. It will also destroy the heritage of many prehistoric peoples, retard land-claim litigation and narrow religious rights and freedoms.

This loss to the world, caused by greed, ignorance and shortsighted zealotry, will unfortunately harm the very people it is meant to help. Custody of remains should be given to only the biologically determined, direct next-of-kin. Others should be kept in perpetuity for study.

E.J. NEIBURGER

Ethnic Minority Council of America, 33263 North Cove Road,

Grayslake,

IIlinois 60030

USA

1. Bahn, P. Nature 342, 123-124 (1989),

2. Gregg, J. Paleopath. Newsletter 67, 7 (1989).

3. Argus Leader (Sioux Falls, SD) p. $6 E$ (7 August, 1988)

Santa Barbara News p. A8, B3. (3 March, 1987)

Kansas City Star (26 February, 1989)

6. Time p. 29 (10 July, 1989).

7. inouye, D. US Senate Bill 978 (May 1989).

8. Trends In Indian Health 1989 (US Indian Health Service, 1989 )

\section{Looking for a link}

SIR-Aldhous's News report ${ }^{1}$ does much to shed light on the controversial issue of the relationship between bovine spongiform encephalopathy (BSE) and its human counterpart, Creutzfeldt-Jakob disease. BSE is an impressive recent example of interspecies transfer of an infectious agent, in this case the apparent transfer of scrapie from sheep to a new host species, cattle.

Remarkably, a similar transfer seems to have occurred before in at least one other species under much the same circumstances, resulting in the disease now termed transmissible mink encephalopathy (TME). TME was first identified in 1947 on a mink ranch in Wisconsin ${ }^{2}$, and further outbreaks were reported in 1961 and 1963. Like BSE, these outbreaks resulted in high fatality rates among adult animals on affected farms. Investigation of the outbreaks ${ }^{2}$, supported by additional evidence from a 1965 outbreak in Finland $^{3}$, suggested a probable origin from feed which incorporated sheep byproducts and was putatively contaminated with scrapie.

As beef by-products were also included in the feed, transmission via infected cattle, rather than directly from sheep, cannot be excluded. Experimental inoculation of mink with the agent causing scrapie resulted in a TME-like spongiform encephalopathy ${ }^{4}$, confirming an association between scrapie and TME, although not all strains of scrapie caused disease in mink $^{3.5}$. Scattered outbreaks of TME have been identified since the 1960 s in Canada and Europe ${ }^{5}$, but TME has not recently been reported in the United States.

Although interspecies transfer of infec- tious agents is believed to be of great importance in the emergence of disease ${ }^{6}$, most are recognised long after the fact, and so little is known about specific events and mechanisms involved in transfer. BSE, and the earlier transfer of TME, are among the few well-documented instances. Others may be the morbillivirus implicated in seal deaths in the North Sea and canine parvovirus 2. As Aldhous points out ${ }^{1}$, Creutzfeldt-Jakob disease is rare even though scrapie has been known in sheep for at least two centuries, and the possibilities of human infection in a manner comparable to the acquisition of BSE by cattle have presumably been high.

The factors causing outbreaks of diseases like BSE and TME in cattle and mink are unknown, nor is it clear why such outbreaks have apparently not occurred in humans despite probable exposure to the same infectious sources. Further research on BSE may help to provide some of the answers.

The Rockefeller University,

STEPHEN S. MORSE 1230 York Avenue,

New York, New York 10021-6399, USA

1. Aldhous, P. Nature 343, 196 (1990)

2. Hartsough, G.R. \& Burger, D. J. infect. Dis. 115, 387-392 (1965).

3. Marsh, R.F. \& Hanson, R.P. in Slow Transmissible Diseases of the Nervous System (eds Prusiner, S. B. \& Hadlow, W.J.) Vol. 1, 451-460 (Academic, New York, 1979).

4. Hanson, R.P et al Science $172,859-861$ (1971).

5. Marsh, R.F. in Slow Virus Diseases of Animals and Man (ed. Kimberlin, R.H.) 359-380 (Elsevier/North-Holland, Amsterdam, 1976)

6. Morse, S.S. \& Schluederberg, A. J. infect. Dis. (in the press)

\section{Origins of segment periodicity}

SIR-The analysis of Hox genes in vertebrates has revived the old problem of the origin of segmentation. The consensus ${ }^{1}$ is that "segmentation seems to have arisen separately in the lineages that lead to the arthropods and vertebrates". While this is the position taken by most textbooks (and assumed to be correct by most readers), it is clear that the lines of evidence on which this view is based are all quite arguable. A second, more serious problem is that the insight provided by the genetic analysis of segmentation in Drosophila is not, as yet, to be found in zoology textbooks.

A chief conclusion of this genetic analysis is that the primary event in segmentation is the establishment of a periodic expression of certain genes along the anteroposterior axis (see ref. 2). The first detectable signs of ectodermal segmentation occur long after this periodic organization has taken place. Furthermore, the manifestation of periodicity may differ according to tissue or developmental stage: for example, the domains of action of homeotic genes are parasegmental, that is, out of phase with the segments them- 